\author{
山口章三郎** 大 柳 康** \\ 村本 幸 保***近 藤 和 為***
}

\title{
Effects of Test Conditions on the Impact Resistance of Plastics by the Free Falling Ball Method
}

by

\section{Yukisaburo Yamaguahi, Ko Oyanagi, Yukiyasu Muramoto and Kazutame Kondo}

(Kōgakuin University, Tokyo)

The present study has been made to inquire experimentally into the effect of testing conditions, such as the gripping pressure on the specimen, the size of the specimen and the weight of the ball, upon the impact resistance of some plastics in the experiment worked by the falling ball method.

The results obtained are as follows;

(1) The gripping pressure has the greatest influence on the impact resistance, and the greater the pressure is, the less the impact resistance is.

(2) The impact resistance increases with the increment of its supporting distance and the thickness of the specimen, but generally it does not increase with the increment of the breadth of the specimen.

(3) The required falling height $H$ to break the specimen is lowered by the increment of the weight $W$ or the size of the falling ball, but the energy $W H$ to break the specimen is little affected by that.

(Received Sep. 18, 1967)

\section{1 緒言}

プラスチックの落球衝撃試験法については $\mathrm{ASTM}^{* 1}$ BS およよ゙ JIS そそその1 部がそれぞれ規格化されてい るが，他の衝撃試験法のように一般的に用いられてい ない．乙の方法は実際の衝撃荷重に対する具体的な強 度を測定できて，設計の基礎資料となる点では，振子 型衝撃試験法では得られない利点をもっている.

本研究では, 落球衝撃試験法によって, どの程度の プラスチックが衝撃強度測定に適用できるかについて まず実験的に検討し，次いで適用できるプラスチック について各種試験条件すなわち試片つかみ圧力, 試片 支点間距離，試片の幅と厚さおよび落球の重量と大き さなどによって衝撃強度がどの程度影響されるかにつ いて実験的に明らかにして，ての種試験法における標

\footnotetext{
* 原稿受理 昭和 42 年 9 月 18 日

** 正会員 工学院大学 東京都新宿区角筈 2 丁目

**** 工学院大学 東京都新宿区角筈 2 丁目
}

準試験法を定める基礎を求めようとした，なお，引張 衝撃試験による衝撃強度と本法によるものとの関連に ついても少々実験的に検討した。

\section{$2 \cdot 1$ 試験装置}

\section{2 実 験の方 法}

実験に用いた落球衝撃試験装置は, Fig. 1 亿示す上 島製作所製のもので，試験片はその両端面を支持板間 にはさまれ，締付ボルトによって加圧固持さるもので， 上部ビームに電磁石によって保持されている鋼球ハン マが，電源を切られるととによって試片中央に垂直に 落下する，ハンマの高さは左右両端の支柱にささえら れ上下にスライドするビームの位置によって種々に変 えられる，本実験では，所定の高さより高いところま

*1 ASTM (D1709-62T)

*2 BS 306B

*3 JIS K 6745 (1963) およひ同6718 (1959) 


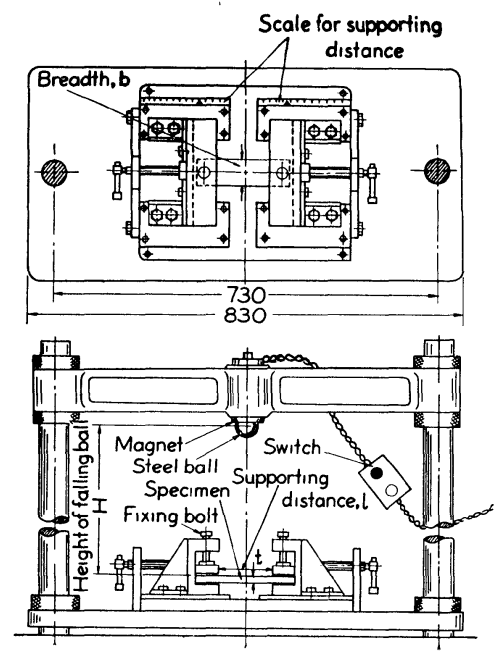

Fig. 1. Test apparatus.

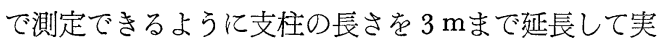
験した。

試験片の支点間距離は規定の $100 \mathrm{~mm}$ 以外の長さに するためには，締付ボルト台を左右に移動するととに よって調節するととができる。

\section{$\mathbf{2} \cdot \mathbf{2}$ 試 験片}

実験に用いた材料はTable I 亿示すフェノール積風 板,メチルメタアクリレート（以下アクリルと略称す る), ABS 樹脂, 塩化ビニルおよびソーダガラスの 5 種で，それぞれ板状の既製品を切断加工によって作成

Table I. Materials of specimen.

\begin{tabular}{|c|c|c|c|}
\hline \multicolumn{2}{|c|}{ Materıals } & \multirow{2}{*}{$\begin{array}{c}\text { Detalls } \\
\begin{array}{l}\text { "Sumilite" : PL-FLE-2 } \\
\text { (Sumitomo Bake Co.) }\end{array}\end{array}$} & \multirow{2}{*}{$\frac{\text { Note }}{3 \times 1000 \times 1000 \mathrm{~mm} \text { plate }}$} \\
\hline 1 & $\begin{array}{l}\text { Phenolics } \\
\text { laminate }\end{array}$ & & \\
\hline 2 & Acrylics & $\begin{array}{l}\text { "Acrylite-100A" } \\
\text { M.M.A. } \\
\text { (Toyo Rayon Co.) }\end{array}$ & $\begin{array}{c}3 \times 1000 \times 2000 \mathrm{~mm} \\
\text { plate }\end{array}$ \\
\hline 3 & $\begin{array}{l}\text { ABS } \\
\text { resin }\end{array}$ & $\begin{array}{c}\text { "Styrac-200" } \\
\text { (Asal Daw Co.) }\end{array}$ & $(1-3) \times 1000 \times 2000 \mathrm{~mm}$ \\
\hline 4 & PVG & $\begin{array}{c}\text { Hard PVG } \\
\text { (Takıron Chem. Co.) }\end{array}$ & $(1 \sim 3) \times \underset{\text { plate }}{1000 \times 2000 \mathrm{nim}}$ \\
\hline 5 & Glass & Soda glass & $(1 \sim 6) \mathrm{mm}$ thickness \\
\hline
\end{tabular}

Table II. Test Conditions.

\begin{tabular}{|c|c|c|c|c|}
\hline \multirow{2}{*}{1} & \multirow{2}{*}{\multicolumn{2}{|c|}{$\begin{array}{l}\text { Pressure on } \\
\text { specimen } \\
\text { fixed }\end{array}$}} & $\begin{array}{l}\text { Twisting moment applied } \\
\text { to bolt } T(\mathrm{~kg}-\mathrm{cm})\end{array}$ & $0,50,150,280$ \\
\hline & & & $\begin{array}{c}\text { Miean pressurc } \\
p\left(\mathrm{~kg}-\mathrm{cm}^{2}\right) \\
\end{array}$ & $0,12,36,67$ \\
\hline 2 & \multicolumn{3}{|c|}{$\begin{array}{l}\text { Distance between fixed } \\
\text { points } l(\mathrm{~mm})\end{array}$} & $75,100,125,150$ \\
\hline 3 & \multicolumn{3}{|c|}{ Breadth of specimen $b(\mathrm{~mm})$} & $37.5,50,75,100$ \\
\hline 4 & \multicolumn{3}{|c|}{ Thickness of specimen $t(\mathrm{~mm})$} & $1,2,3,5,6$ \\
\hline \multirow{2}{*}{$\frac{5}{6}$} & \multirow{2}{*}{$\begin{array}{c}\text { Falling } \\
\text { ball }\end{array}$} & \multicolumn{2}{|r|}{ Werght (Equal size) $W(\mathrm{~kg})$} & $0.6,1,1.2, \frac{1.44}{(63 \phi)}$ \\
\hline & & \multicolumn{2}{|r|}{ Size (Solıd ball), $D(\mathrm{~mm})$} & $36 \sim 71.6$ \\
\hline
\end{tabular}

した. なお，引張衝撃試片は打抜加工によって所定の 寸法にした。

\section{$2 \cdot 3$ 試験条件}

落球衝撃試験の試験条件として, Table II そ示す次 の六つについて検討した。

2・3・1 試験片押え平均圧力 試験片の両端面を 加圧固持するときの端面にかかる平均圧力 $p$ は, 締付 ボルトにかけるねじりモーメント $T$ による締付力 $Q と$ 固持端面積を $A$ とすると, $p=Q / A\left(\mathrm{~kg} / \mathrm{cm}^{2}\right)$ とよって表 わされる．試験に用いたTおよびpはTable II に示す 5 種とした.

$\mathbf{2} \cdot \mathbf{3} \cdot \mathbf{2}$ 支点間の距離 試験片固持端面間の距離 $l$ を試験片支点間距離として, 試験片の長さおよび締付 ボルト台の位置を変えることによって, Table II に示 すように 4 種に変えた。

$\mathbf{2} \cdot \mathbf{3} \cdot \mathbf{3}$ 試験片の幅 支点間距離に直角方向の試 験片の長さを試験片の幅とし，この寸法は標準では50 $\mathrm{mm}$ とされているが, Table II に示すように37.5〜 $100 \mathrm{~mm}$ の範囲で 4 種にして試験した.

$\mathbf{2 \cdot 3 \cdot 4}$ 試験片の厚さ 試験片の厚さは既製品に 制限され，いずれの材料にも， Table II に示す1〜 $6 \mathrm{~mm}$ の範囲のどの寸法のものもすべて準供するとと はできなかった。

$2 \cdot 3 \cdot 5$ 落球(ハンマ)の重量 ハンマの外径を同 しくして, 中空, 中実, 中空部に鉛または水銀を入れ て重量だけをTable II に示すように，0.6〜1.44kgの 範囲で 4 種に変えた。

2・3・6 落球(ハンマ)の大きさ ハンマはすべて 中実鋼球で外径すなわち重量ともTable II に示すよ

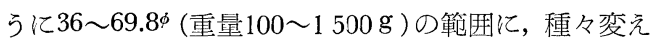
た.

\section{$2 \cdot 4$ 試験の方法}

落球衝撃試験方法は同一条件で一定の高さから試験 片 5 枚について落球衝撃を与え, 破䘫した試験片数の 5 枚に対する比率を破榬率とした．しの場合の破壊と は破断したものおよびクラックの生じたものをいう。 落球衝撃值は $50 \%$ 破墔するに要する高さまたは，高さ と重量との積の破壊落球エネルギで表わすととができ るので, 縦軸を落球高さ，横軸を破壊率とするFig. 2 のような関係線図を求め，乙の関係線 $\mathrm{AB}$ と $50 \%$ 破壊 率を表わす直線との交点 $H$,落球衝撃高さであり, こ れにハンマの重量 $W$ を乘じた $W H$ が落球衝熬值 $U \mathrm{~kg}$ $\mathrm{cm}$ とすることができる。なお，Hの值は破壊率 $0 \%$ の最大高さ $H_{1}$ と破壊率 $100 \%$ 最低高さ $H_{2}$ が求められ ると次式で表わされる。

\footnotetext{
*4 BS $50 \phi \mathrm{mm} * 2$
} 


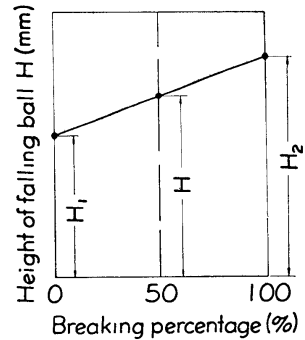

Fig. 2. Method to obtain $H$.

L type

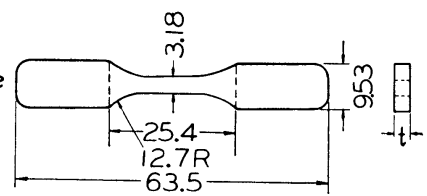

Fig. 3. Tension impact specimen.

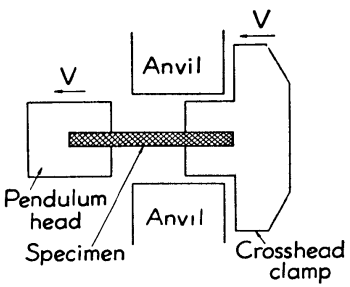

Fig. 4. Tension impact machine (Schematic).

$$
H=H_{1}+\frac{H_{2}-H_{1}}{2}=\frac{H_{2}+H_{1}}{2}
$$

また，引張衝撃試験法は，ASTM ${ }^{* 5}$ とよる方法で, 容量 $30 \mathrm{~kg}-\mathrm{cm}$ の振子形衝撃試験機の衝撃速度 $3.3 \mathrm{~m} / \mathrm{sec}$ でFig. 3 亿示す試験片をFig. 4 亿示す衝撃部の装置で 引張衝撃試験を行ない, 破壤に要したエネルギ $E$ $(\mathrm{kg}-\mathrm{cm})$ を断面積 $A$ で割った值 $U$, すなわち $U=E / A$ $\left(\mathrm{kg}-\mathrm{cm} / \mathrm{cm}^{2}\right)$ をもって引張衝撃強度とした。 なお，両衝撃試験とも試験環境は室温 $20 \pm 3{ }^{\circ} \mathrm{C}$, 湿度 $65 \pm 15 \% R H$ の状態とした。

\section{3 実験の結果と考察}

\section{$3 \cdot 1$ 材料による落球衝撃法の適否}

Table I 亿示す 4 種のプラスチックとガラスの中で, 標準ハンマ $1 \mathrm{~kg}$ で高さ $3 \mathrm{~m}$ 以内で破壊するものはフェ ノール積層板，アクリルおよびガラスの 3 種で ABS 樹脂と塩化ビニルは引張衝撃強度は求められるが, 落 球衝撃によっては明りょうな破壊を生じないため，そ の衝撃強度も求めることができない。てれらより強い 衝撃強度をもつポリカーボネート, ナイロン 6 , ポリ アセタールおよびポリプロピレンなどの熱可塑性プラ スチックも同様に，乙の程度の容量の試験装置で破壤 が生じないため測定不可能である。すなわち，現用の 落球衝撃試験機は板状の熱硬化性プラスチックと, 比

*5 ASTM D 1822-61T
較的もろい熱可塑性プラスチックの1部についてのみ 適用できるもので，すべてのプラスチックには適用で きない。

\section{$3 \cdot 2$ 試験片押え圧力の影響}

試験片の寸法を $150 \times 50 \times 2$ (アクリルは 5 ) $\mathrm{mm}$ ，支

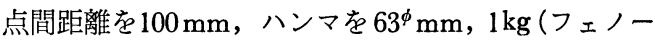
ルに対しては $0.5 \mathrm{~kg}$ ）のそれぞれ一定条件として，試 験片押え平均圧力を $0 ， 12 ， 36$ および $67 \mathrm{~kg} / \mathrm{cm}^{2}$ とし た場合の落球衝撃破壊高さ $H$ と破壊率との関係を求め ると，フェノールに対してはFig. 5，アクリルに対し てはFig. 6 となる.

てれらの図から各試片押え圧力 $p$ 亿対する落球破壊

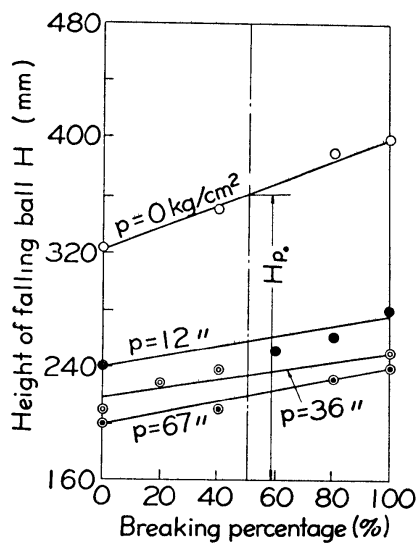

(Size : $150 \times 50 \times 5 \mathrm{~mm}, W: 1 \mathrm{~kg}(63 \phi), l: 100 \mathrm{~mm})$

Fig. 5. Relations between $H$ and breaking percentage for various pressures $p$ in acrylics.

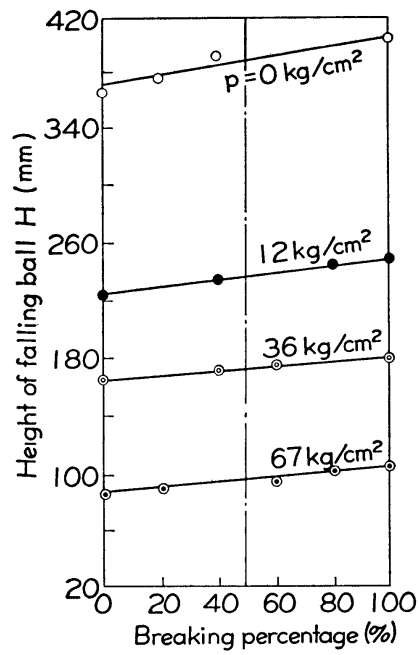

(Size : $150 \times 50 \times 2 \mathrm{~mm}, W: 0.5 \mathrm{~kg}, l: 100 \mathrm{~mm}$ )

Fig. 6. Relations between $H$ and breaking percentage for various pressures $p$ in phenolics. 


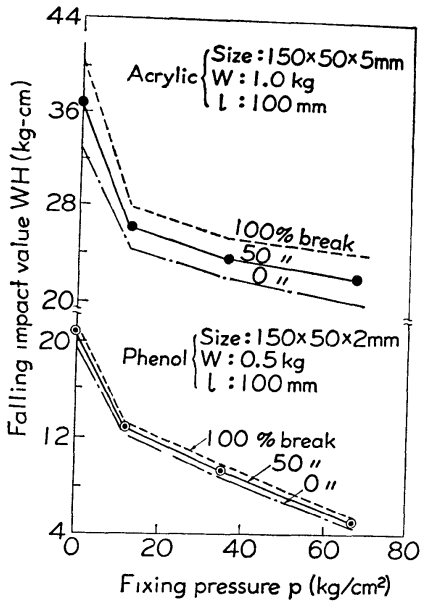

Fig. 7. Relations between falling impact value $W H$ and pressure $p$ for acrylics and phenolics.

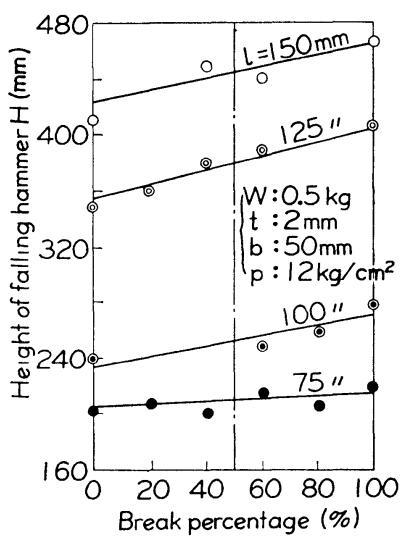

Fig. 8. In phenolics.

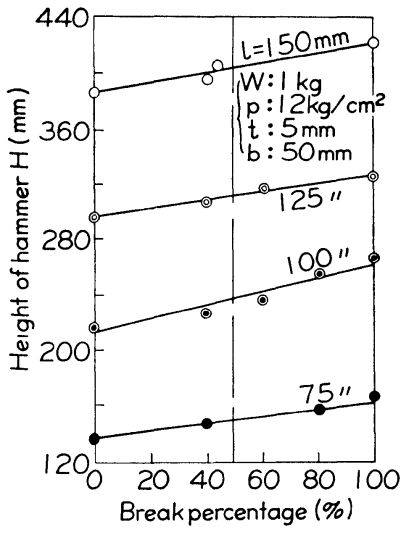

Fig. 9. In acrylics.

Figs. 8, 9. Relations between $H$ and breaking percentage for various supporting distances $l$.

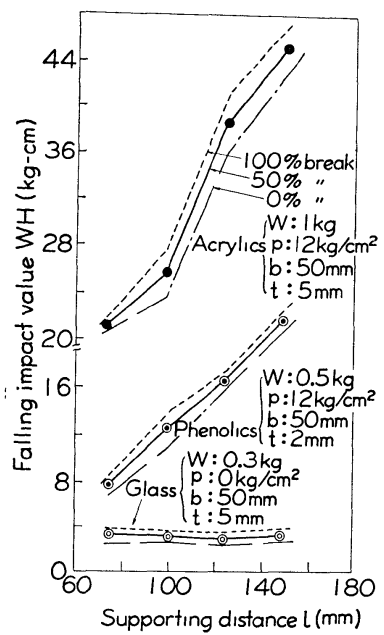

Fig. 10. Relations between falling impact value $W H$ and supporting distance $l$ in acrylics, phenolics and glass.

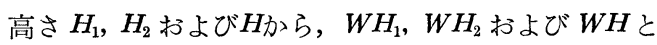
の関係を図示すると，Fig. 7 となる。図から明らかな ように，いずれのプラスチックも試片押光圧力が大き くなるほど落球衝撃強度 $U(=W H) \mathrm{kg}-\mathrm{cm}$ は低下し, 特に押え圧力 $p$ か $12 \mathrm{~kg} / \mathrm{cm}^{2}$ 以下の範囲においてての傾 向が著しい。

\section{3・3 支点間距離の影響}

試験片の幅と厚みを一定とし, 試片押え平均圧力を $12 \mathrm{~kg} / \mathrm{cm}^{2}$, ハンマ重量を $1 \mathrm{~kg}$ (フェノールは $\left.0.5 \mathrm{~kg}\right)$ と $し て$, 試験片の支点間距離をTable II 亿示すように種 々に変えて, 落球衝撃試験を行なった結果を, 各支点 間距離について落下高さと破壊率との関係で示すと, フェノールはFig. 8，アクリルはFig. 9 となる。乙れ らの図から, 前記同様にして落球衝撃強度 $W H_{1}, W H_{2}$, WHと支点間距離との関係を示すと，Fig. 10 となる。 図はフェノールおよびアクリルとてれらと同じように して求めたガラスにおける関係を示している。図から 明らかなように，両プラスチックにおいては，支点間 距離にほぼ正比例して衝撃強度は大きくなる。しかし， ガラスにおいては支点間の距離の影響がほとんど現わ れない。

\section{$3 \cdot 4$ 試験片の幅と厚さの影響}

フェノールに対しては試片押光圧力 $12 \mathrm{~kg} / \mathrm{cm}^{2}$, 八 ンマ重量 $0.5 \mathrm{~kg}$, 試片厚み $2 \mathrm{~mm}$, アクリルに対して は試片押光圧力 $12 \mathrm{~kg} / \mathrm{cm}^{2}$, ハンマ重量 $1 \mathrm{~kg}$, 試片厚 み $5 \mathrm{~mm}$ ，ガラスに対しては試片押光圧力 $0 \mathrm{~kg} / \mathrm{cm}^{2}$, ハンマ重量 $0.3 \mathrm{~kg}$, 試片厚み $5 \mathrm{~mm}$ とし, いずれも支 点間距離を $100 \mathrm{~mm}$ として，試片の幅を $40,50,80 お$ よび $100 \mathrm{~mm} の 4$ 種に変えて落球試験を行ない，それ ぞれの落球衝撃強度 $W H_{1}, W H_{2}$ および $W H(\mathrm{~kg}-\mathrm{cm})$ 
と試片幅との関係を示すと, Fig. 11 となる。

図から明らかなように，フェノールでは幅 $50 \mathrm{~mm}$ で 衝撃強度は最大となり，それ以上の幅になるとかえっ てての值が低くなり，アクリルではとの範囲における 幅では，幅が大きくなるほど衝撃強度が少し低下する が，ガラスにおいては，乙れと反対に幅が増すほど衝 撃強度は大きくなる。

次いで, 前記同様の条件で, 試片の幅を $50 \mathrm{~mm}$ の一 定として，厚みを $2 \sim 10 \mathrm{~mm}$ の範囲で変えた場合の落 球衝撃強度 $W H$ と試片厚みとの関係を示すと, Fig. 12となる。図で明らかなように，いずれの材料も厚み が増すほど衝撃強度 $U(=W H)$ は大きくなる，実験デ

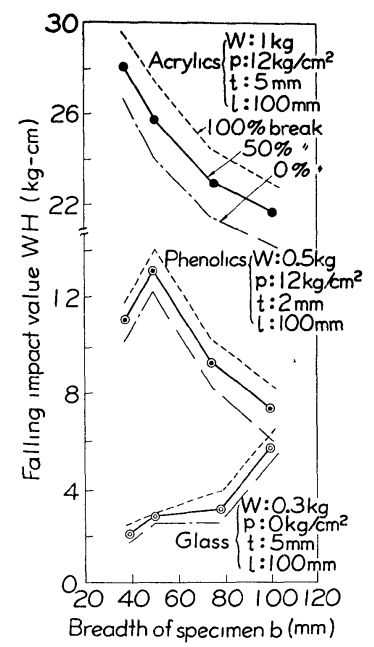

Fig. 11. Relations between falling impact value $W H$ and breadth $b$ of specimen in acrylics, phenolics and glass.

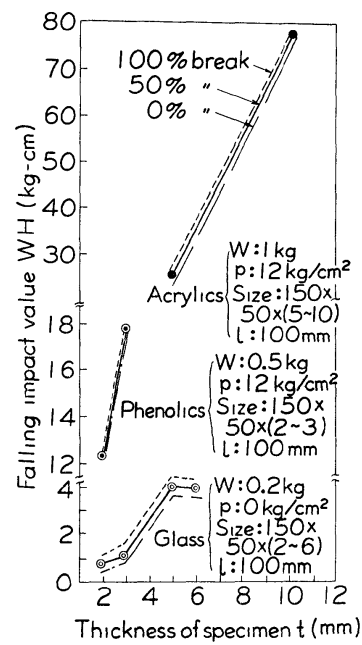

Fig. 12. Relations between falling impact value $W H$ and thickness $t$ of specimen in acrylics, phenolics and glass.
一タが少ないので戦密性を欠くが，てれらの関係線か ら衝撃強度 $U$ と厚み $t$ との関係は次式で表わされ る.

$$
U=c t^{n}
$$

ことで $c, n$ は材料による定数で $n$ の值はフェノー ルおよびガラスに対しては約 1 ，アクリルに対しては 約 1.5 となる.

\section{$3 \cdot 5$ ハンマの重量と大きさの影響}

$150 \times 50 \times 5$ (フェノールは 2) $\mathrm{mm}$ の標準寸法の試 験片で，支点間距離を $100 \mathrm{~mm}$, 試片押え圧力 $12 \mathrm{~kg} /$ $\mathrm{cm}^{2}$ として， ハンマの外径は $63^{\phi} \mathrm{mm}$ の一定とし， 重量を $0.6 ， 1 ， 1.2$ および $1.4 \mathrm{~kg}$ とした場合，フェノ 一ルおよびアクリルに対する落球衝撃破猿高さ $H$ と， ハンマの重量との関係を示すとFig. 13 とり, 重量が

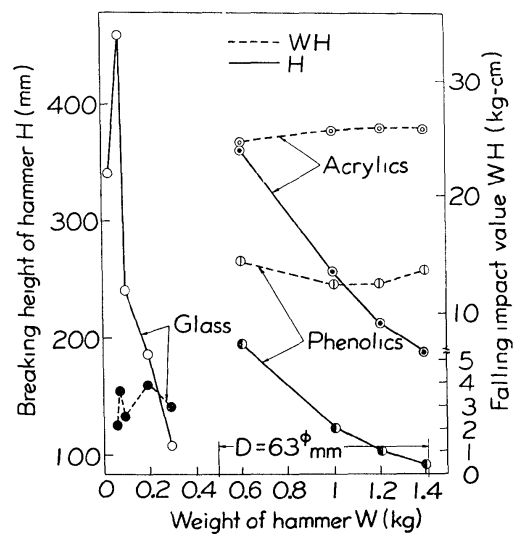

Acrylics $\cdot p: 12 \mathrm{~kg} / \mathrm{cm}^{2}$, s1ze $\cdot 150 \times 50 \times 5 \mathrm{~mm}, l \cdot 100 \mathrm{~mm}$ Phenolies: " , " $150 \times 50 \times 2 \mathrm{~mm}$, " Glass : $p: 0 \mathrm{~kg} / \mathrm{cm}^{2}$, " $150 \times 50 \times 5 \mathrm{~mm}$, "

Fig. 13. Relations between $H$ or falling impact value $W H$ and weight $W$ of hammer for various materials.

大きくなるほど $H$ は小さくなる。しかし，落球衝撃 強度 $U(=W H)$ と重量との関係は同図の点線で示す ように，重量に関係なくWH はほぼ一定となる。な お，ガラスにおいてはハンマ径を小さくして重量を変 えた場合も，ある程度のばらつきはあるが前記のプラ スチックと同様に, 重量が大きくなるほど破壊落下高 さ $H$ は小さくなるが，衝撃強度 $W H$ はほぼ一定で ある。

前記と同じような条件で, ハンマを無空で直径を $50.8^{\phi}(0.5 \mathrm{~kg}), 63^{\phi}(1 \mathrm{~kg})$, および $69.8^{\phi}(1.5 \mathrm{~kg}) \mathrm{mm}$ とし た場合の破壊落下高さ $H$ と球の径 $D$ との関係を示 すと，Fig. 14 となる。网から明らかなように，ハン マの外径すなわち重量が大きくなるほど破壊落下高さ $H$ は小さなるが，落球衝撃強度 $W H$ の大きさはあ まり影響されない，厳密には，アクリルにおいて球が 


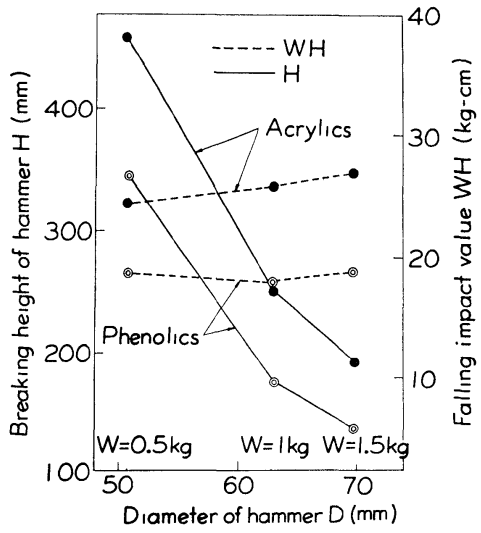

Acrylics : Size ; $150 \times 50 \times 5 \mathrm{~mm}, p: 12 \mathrm{~kg} / \mathrm{cm}^{2}, l: 100 \mathrm{~mm}$

Phenolics : Size ; $150 \times 50 \times 2 \mathrm{~mm}$,

Fig. 14. Relations between $H$ or $W H$ and diameter $D$ of ball hammer for various materials.

大きくなるほどわずかに WH の值は大きくなるが, フェノールにおいては明らかな傾向は認められない.

\section{3・6 引張衝撃値亡落球衝撃值との関係}

プラスチックの落球衝撃強度を試片の寸法に関係な く表わす方法として, 落球比衝撃強度 $U_{s}$ という概念 をかりに考える。すなわち落球衝撃強度に対する試片 の幅の影響は割合少ないのでしれを無視し，試片の厚 みの影響は(2)式に示したように，その $1 \sim 1.5$ 乗に比 例するので，乙こでは簡単のため厚み $t$ 亿比例すると 考えて，支点間距離 $100 \mathrm{~mm}$ 亿おいて単位厚さ $(\mathrm{cm})$ あ たりの落球衝撃強度を落球比衝撃強度 $\left\{U_{s}(=W H / t)\right.$, $\mathrm{kg}-\mathrm{cm} / \mathrm{cm}\}$ とする. したがって Fig. 12から厚さ $2 \mathrm{~mm}$ のフェノールの落球衝撃強度 $U(=W H)$ は $13 \mathrm{~kg}-\mathrm{cm}$ であるから，その落球比衝撃強度 $U_{s}$ は $U / t$ すなわ ち $65 \mathrm{~kg}-\mathrm{cm} / \mathrm{cm}$ となり, 同様にしてアクリルに対す るこの值は $52 \mathrm{~kg}-\mathrm{cm} / \mathrm{cm}$ となる。

Fig. 3 に示した試片による引張衝撃值 $E_{t}$ は，フェ ノール34.6，アクリル 29.3, ABS 樹脂 40.4, 塩化ビ ニル $26.9 \mathrm{~kg}-\mathrm{cm} / \mathrm{cm}^{2}$ である.

いま， $U_{s}$ と $E_{t}$ との関係をグラフで示すと Fig. 15 となり，フェノールとアクリルにおいては両衝撃強度 の值はほぼ正比例関係にあるが，現用の落球衝撃試験 で破壊しなかった，すなわちスケールアウトしたABS

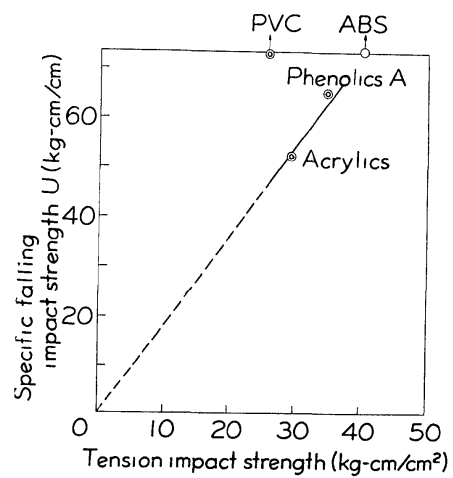

Fig. 15. Relations between specific falling impact strength and tension impact strength.

と塩化ビニルはこの関係線から著しくはずれると考え られる。したがって，ての両衝撃強度はアクリルとフ エノールなどのように直線 OAで表わされる相関性の あるものもあり，また $\mathrm{PVG} と \mathrm{ABC}$ 樹脂のように 落球衝撃值が著しく高く，上記の相関線からはずれる ものもあると考朰れる。

\section{4 結 論}

以上の実験結果を要約して，次の結論が得られる。

（1）現用の落球衝撃試験では，比較的もろい熱硬化 性プラスチックと一部の熱可塑性プラスチックのみし か測定できない.

（2）試験片押え圧力が大きくなるほど落球衝撃強度 は低くなる。

（3）試験片の支点間距離が大きくなるほど，落球衝 撃強度は大きくなる。

（4）落球衝撃強度は試験片の厚みの $1 \sim 1.5$ 乗に比 例する。

（5）落球衝撃強度は試験片の幅が大きくなると少し 低下する傾向がある。

（6）ハンマの重量または大きさが大きくなると，落 球破壤高さは低下するが，破壤に要するエネルギすな わち落球衝撃強度 $W H$ はほとんど一定である。

（7）落球衝撃強度と可張衝撃強度は材料の種類によ ってはその相関値が著しく異なる。

（昭和 42 年 5 月 22 日 日本材料学会第 16 期総会譵演会にて講寅） 